\title{
IMPACT OF RETAIL STORE ENVIRONMENTAL MARKETING CUES ON CONSUMER BUYING PHYSIOLOGY
}

\author{
Arti Lata \\ Shri Mata Vashino Devi University, Jammu \& Katra, India \\ Abhishek Ranjan Singh \\ Lecturer, Norton University, Phnom Penh, Cambodia
}

\begin{abstract}
The research objective is to identify and verify the cause-and-effect relationship environmental sensory components (i.e., display and layout, music, light and cleanliness and participant), consumer emotion, and consumer behaviour intension in a apparel context by applying the Mehrabian-Russell, Stimuli-Organism-Response model. The result showed the acceptance level of model fit ( $\chi 2 / d f 4.189, p<0.001$ CFI 0.869**GFI $0.808^{*}$ RMSEA $0.072^{* *}$ ) for the proposed model. Store display and layout, light had significant impact on pleasure of emotion, and music and cleanliness and participant had direct impact on customer behavior intension. Store pleasure significantly influences on customer behaviour intension: however, arousal and customer retail experience did not. These study results have important implication for the apparel retail industry in understanding how to create and manage their sensory environment resource to affect customer's emotion and behaviour intension
\end{abstract}

Key words: MR Model; Store Sensory Cues; Consumer Behaviour; Consumer emotion; Retail Industry; Multi-sensory effect.

Cite this Article: Arti Lata and Abhishek Ranjan Singh, Impact of Retail Store Environmental Marketing Cues on Consumer Buying Physiology, International Journal of Management, 11(12), 2020, pp. 3148 -3165.

http://iaeme.com/Home/issue/IJM?Volume $=11 \&$ Issue $=12$

\section{INTRODUCTION}

The Apparel retail sector in India is one of prominent and fast rising booming trade sector in the economy; through having total market size of US\$ 65 billion in 2016-2017 and expected to grow US\$ 223 billion by 2021 (IBEF, 2017). The Apparel retail industry has been expending at a compound annual rate of 6.8. Since 1998. This growth is highly dominated by unorganized retail sector comprising 94 per cent of the overall retail bazaar. Structured retail in India is predictable to be 9 percent of entirety retail market by 2015 and 20 percent by 2020 , where 
Apparel sector is accounted for the largest share 8\% in Indian retail business, following by food and grocery and consumer durable. Health and beauty segment contributed the lowest $1 \%$ of the total sector revenue. A varied set of retail formats have emerged over the last few decades to cater to the Indian consumer. As noted by Sinha and kar (2007), it is difficult to fit a successful international format directly and expect a same performance in India consideration the diversity in term of taste and choices existing in India. As they have predicting, and in the line with the casualties and grapping challenges of achieving desired profit level's, there has been large scale experimentation in the adoption of winning retail format to suit different geographical and segments of customer. In addition, the rural population of the country which is more than 70 per cent of the country 1.21 billion population has one of driving factor of Apparel organized retailers to look for new areas of growth. But the growth trends, issues and challenge's in rural markets are somewhat different with compare to urban areas. But, as viewed by Kohli and Bhagwati (2011) that even though Apparel retail industry analyst are optimistic in the organized retail sales projections, they reasoned that the industry is likely to fall behind growth rate.

Under the current scenario, Apparel organized retail market in India has been booming and successfully enter in the market and also showing continues growth by the completing the existing players in market. In this environment, customer retention is becoming tuff as shoppers become savvier and willing to shop at a wide variety of stores and across a broad range of retailing formats. Thus, the purpose of the current researches as to expanded the near into the formation of store satisfaction along with shopping satisfaction. This research proposes to test theoretical Buying behaviour framework to explore store elements and its ability to affects customers emotions, attitude and behaviour intention.

Walters \& White (1987) described to the term "visual merchandising", as the set of activities which helps into merchandise identification and its selection with effective merchandise display. Explained this term as "everything the customer view by necked eye, external and internal both factors that build a positive perception of a business and result leads is catch attention, interest, desire and response on the part of the customer shopping behaviour" (Ebster and Garaus , (2011).Diamond \& Diamond (2007) elaborated on the goal of visual merchandising in their attempt to explain the concept visual merchandising. Store retailers adopted visual merchandising technique with following the basic objective of attracting customers in order to sell product (Bastow-Shoop et al., 1991).Therefore, visual merchandising has become more concerned with both how the product and/or brand are visually communicated to the customers a (Wanninayake \& Randiwela, 2007). The role of visual merchandising is to create awareness among customers about a product and provide associate information about as explained by, recall customers (Gajanayake, Gajanayake, \& Surangi, (2011).

According to (Mills et al., 1995), Visual merchandising involved as both interior to exterior presentation technique such as; exterior display window, interior displays i.e. Form displays, floor wall merchandising along with promotion signage. Layout, shelf space techniques, lighting, colors, cleanliness, and music Agnihotri \& Oburai, (2009). Window display is one of most important and prominent technique with goal to attract attention and ultimately to enter the store Gajanayake et al., (2011). Store elements such as cleanliness factor of Store impacts the length of stay more with respect to time of customers for shopping, visited frequency of store for shopping and another lighting and colors are also considered as part of the visual merchandising techniques (Ebster \& Garaus, 2011). 


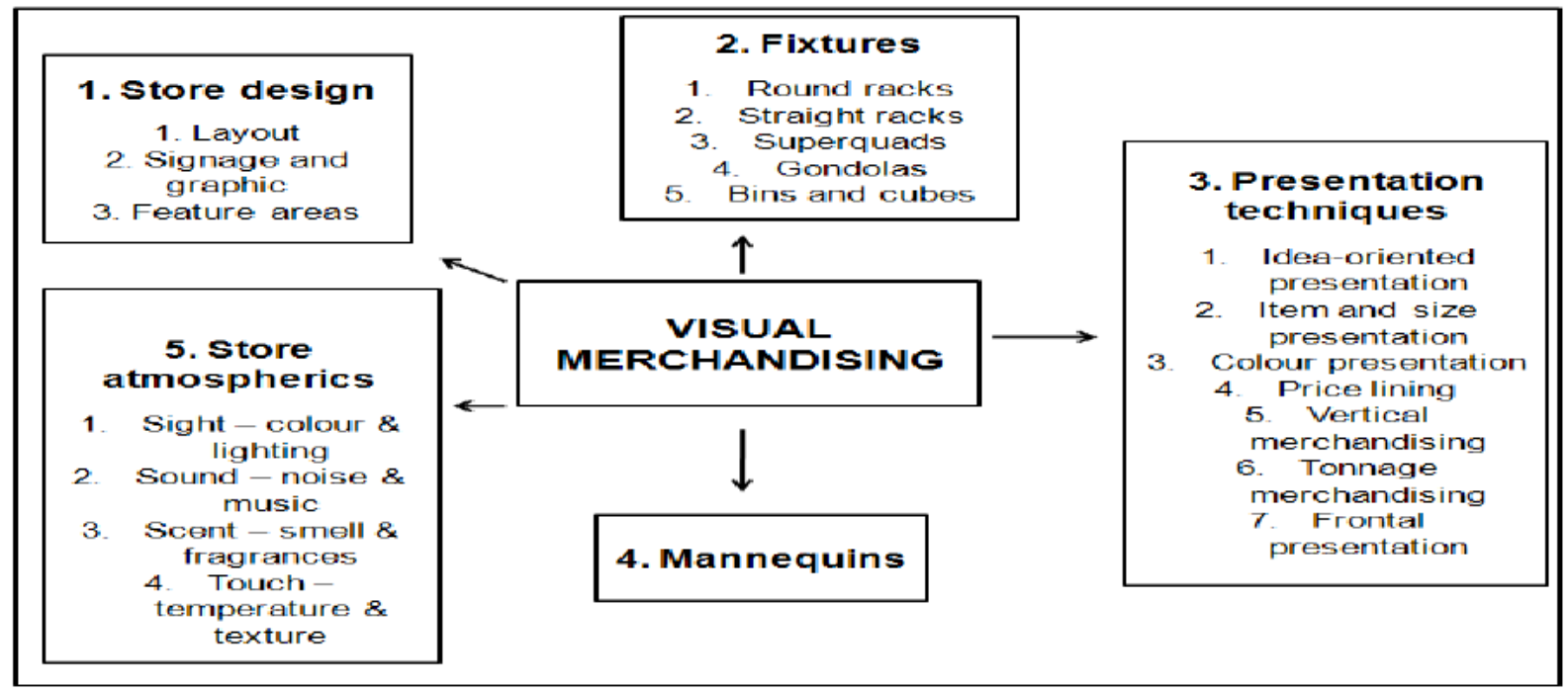

Source: Adapted from Bell and Ternus (2006:20) and Levy et al. (2012: 487-492)

Figure 1 Visual merchandising

\section{LITRETURE REVIEW}

Meharabian and Russell proposed the stimuli-organism-response (SOR) Model that explained environmental stimuli $(\mathrm{S})$ induce emotional reaction $(\mathrm{O})$ and influence ultimate influence consumer's behaviour response (R) (1975). Donovan \& Rossiter (1982) followed, Mehrabian - Russell Model (M - R Model), based on store atmospheric stimuli will effect on customer's emotional response and also impact their approach or avoidance behavior. Spengenberg, Crowley \& Henderson (1996) that pleasant odor of scent could impulse to customer for more buying. Store atmosphere can be positively influence customer's perception on the credibility of salespeople (Sharma \& Stanford (2000). Bitner (1990) study's findings added a term as services cape which affects not only customers but also employee's as both "interact with each other within the organization's physical facility". In addition to personality traits as suggested in the PAD, also hopes, mind states of individuals entering an environment and so on are influencing the impact of services capes on internal responses De Young (1999).

\section{CONCEPTUAL AND THEORACTICAL BACKGROUD OF RESEARCH}

According to (Kotler, 1973) defined the word store atmospherics as "purchasing environments to produce particular emotional effects in the buyer that encourage his purchase probability and studies typically group pretending reactions into two kinds of behaviour - Approach or avoid". Approach behaviour is explained as positive approach other one is avoidance behaviour is explained as negative approach (Mehrabian \& Russell model 1974).

Baker, Levy \& Grewal (1992) described a word service cape is described the "sum of all objective physical factors that can be controlled by the store to success or failure. The basic fundamental of the M-R model suggests using the load of an environment as a general measure of the environment, which intensified the degree of novelty and complexity Mehrabian \& Russell (1974). Comprehensive impact of the environment on the level of pleasure and arousal without environmental measure Donovan \& Rossiter (1982). Later, Donovan et al have tested a 14 item scale measuring information rate. A factor analysis identified five factors with eigenvalues greater than 1.0, of which two were deemed to be unreliable, suggesting that the stimulation measure load is not a good predictor. They content 
that "more realistically, retailers need a taxonomy that applied to manipulative in-store factors" Donovan et al. (1994).

Stimulus

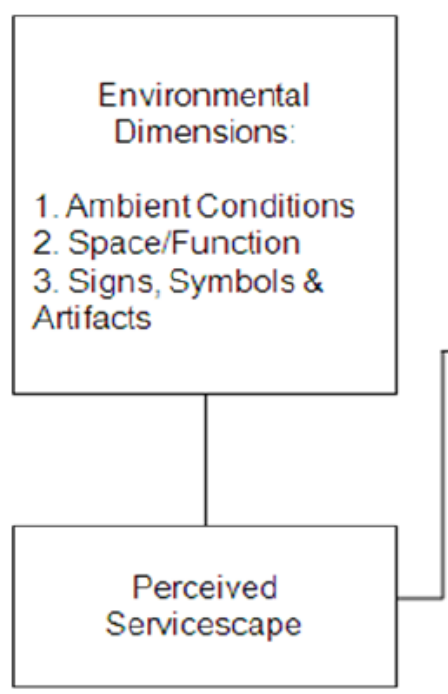

Organism

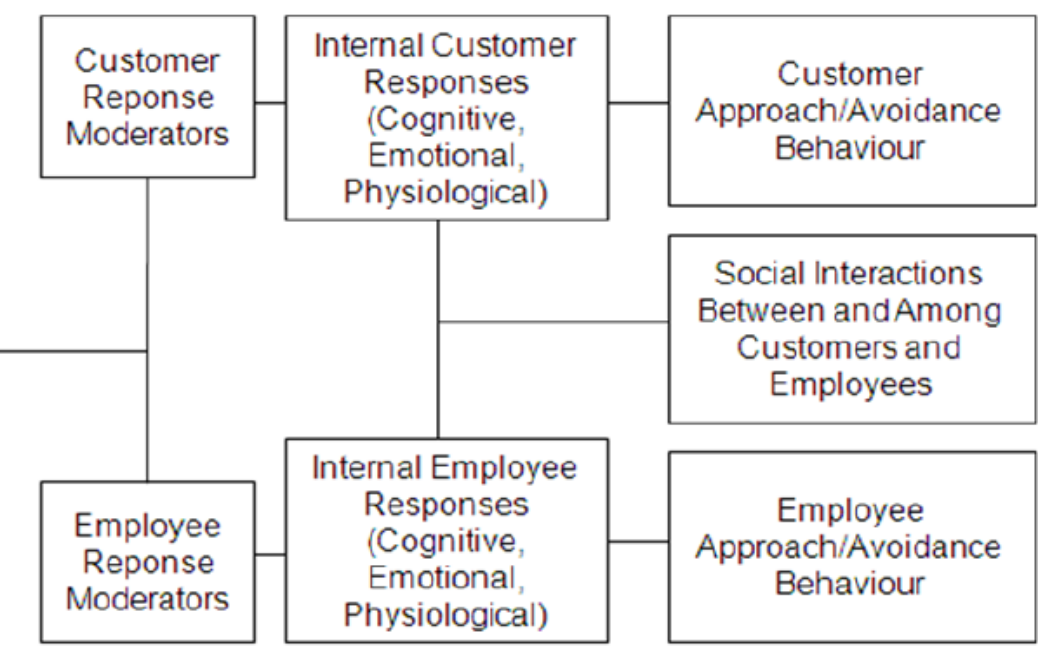

Source: based on Mehrabian \& Russell (1974), Bitner (1992)

Figure 2 Model of Store Atmospherics Effect on Consumer and Employee Behaviour

\subsection{Window Display and Color}

Window display, is visually displaying to products in store at different place and silently guiding to consumer's Kerfoot et al, (2003). Component of window display (e.g. size, style, color) has significantly influence, emotion level (pleasant and arousal) of the consumer's. Mehrabian and Russell (1974) suggested that type of display used by store (e.g. flat, hanging, full size mannequin) influencing a customer's behaviour response positively suggested by Mehrabian and Russell (1974). Kotler (1973) suggested color, brightness, size and Shapes as a visual dimension that influence consumer's buying intension. A warm color (e.g. Pink) is more affective on pleasure-arousal emotions that the customer's extra spending money and time Bellize \& Hite, (1992).

Brightful and colorful environment is correlated with pleasure and arousal Mehardian \& Russell (1974) that attract consumer shopping of pattern Summer \& Hebert (2001). Color, decoration, design were examined to affect customer's emotion and purchase Baker et al, 2002; Spies, Hence \& Loesch, 1997; Tai, \& Fung (1997). The physical environment such as lighting, color, signage style of furnishing, layout and well décor could be controlled by the retailer to increased customer's affective behavior Bitner (1992).

\subsection{Music}

Smith \& Curnow (1966) revealed that customers spend less time in the stores when the music is high. Milliman (1982) experiment results identified that tempo of music affected the speed in which consumers walked around a store. Milliman (1986) father showed that the background music in restaurants affect the time customers remain into the place showing that slow tempo music leads customers spend more time in the restaurant than high tempo music.

Milliman (1982) followed out research in a supermarket and reported that more sales volume is due to played slow music with low volume were fast music, in this order of ideas customers who stay long in a supermarket tend to purchase more than those who spend less 
time. Milliman (1982), conducted an experiment with no music, slow tempo music and fast tempo music and found that the slower shoppers walk through the store,

\subsection{Light}

Ruchi (2003) Lighting is used to give more focus to product and create an atmosphere. Lighting has directly impacted the customer perception towards the retail store image, brand and also their mood to shop in the store. In store lighting influences the customer's perception for the store, valve and also their expenditure Areni \& Kim, (1994). According to James and Mehrabian (1976) in-store lighting is one of the significant factors which have higher impact on consumer behavior. According to Vaccaro, Yacetepe, Baumgarten, and Lee (2008) found that brighter light with having low intensity is creating the positive customer perception for the product.

\subsection{Cleanliness and Participant}

Akinyele (2010) that cleanliness could improve store atmosphere. Cleanliness of a store will create positive impression among consumers and lead them stay for a longer time and also assess them for revisit the store again in future Gajanayake, Gajanayake, \& Surangi, (2011). Fournier (1998) found that relationship between customers and salespersons is inexplicable unless customer not contacting the salesperson regarding their quires. Customer will have different expectations towards salespersons based on types of store atmosphere.

In different types organized retail stores, salesperson will provide different information and responsibility towards their target customers Harris, Harris, \& Baron, (2001). Situational factors that significantly impacted the customer experience with employees and services (Bell, Paul, Morrris, \& Micheal, (1991). Attitude and behavior of the employees also will affect the customers' experiences towards the store Customer feel satisfied when the employees are able to solve their quires. Akinyele (2010) that cleanliness could improve store atmosphere. Cleanliness of a store will create positive impression among consumers and lead them stay for a longer time and also assess them for revisit the store again in future Gajanayake, Gajanayake, \& Surangi, (2011).

Carpenter and Moore (2006) Showed that cleanliness is the most important among other store atmospheric cues that affects customers to buy more things and stay longer. The study has conducted by Gajanayake (2011) and mentioned that mean average value of cleanliness is 3.770, which ranked as second most important store atmospheric stimuli and also proved in his study that cleanliness factor also influences the customer shopping behavior.

\section{THE PROPOSED RESEARCH MODEL FOR STUDY}

The prosed research model is to test the impact of Apparel store atmosphere on the consumer shopping behaviour and to test the impact of store layout and display on shopping behaviour, the impact of music on shopping behaviour, impact of lighting on shopping behaviour, and cleanliness and participant factors on shopping behavior.

A hypothesis derives from theory and is used whether to validate, revise or invalidate theories through research. In this study, buyer's purchase tendency and selected visual merchandising techniques are meant to be the variables which allowed us to define the hypotheses of our research

- HI: Store layout and display significantly influences on pleasure, arousal, customer's retail experiences and behaviour intention.

- HI: Store music significantly influences on pleasure, arousal, customers retail experiences and behaviour intention. 
- HI: Store Light significantly influences on pleasure, arousal, customers retail experiences and behaviour intention.

- HI: Store cleanliness and participants significantly influences on pleasure, arousal, customers retail experiences and behaviour intention.

- HI: Store Pleasure significantly influences on customers retail experiences and behaviour intention.

- HI: Store Arousal significantly influences on customers retail experiences and behaviour intention

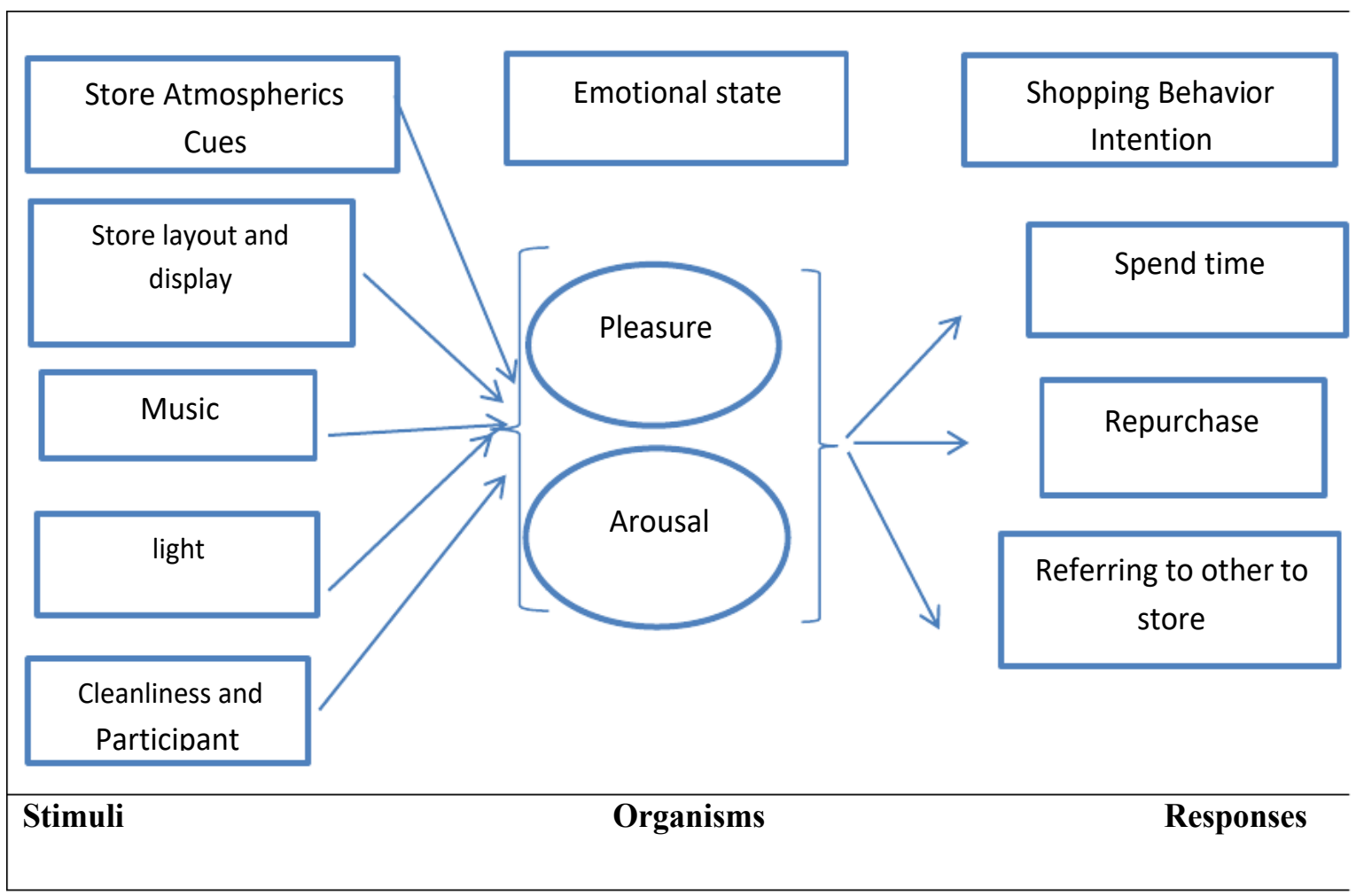

Figure 3 The Proposed Research Model

\section{RESEARCH DESIGN AND SAMPLE}

The research design is divided into two sections; first section is exploratory study and second is descriptive in nature. In the exploratory study the "Atmospheric Cues' of "Apparel Stores" were interviewed to understand and investigate the dimensions of atmospheric cues. The study was purely focused on the impact of atmospheric cues in terms of Apparel retail stores, selected as a product category for conducting this research.

The sample size used is 600 but 100 was outliners hence, total revised sample size total 500.The used sampling technique was mall method, were asked to customer for filled the survey questionnaire form. Thus sampling procedure is purposive in nature. The survey was conducted in Indian organized apparel stores .SPSS 21 and AMOS 21 statically tool has been used to analyses the research data.

\subsection{Data Analysis and Interpretation}

The structural model is tested only after the measurement model is tested by its fitness and reliability after Confirmatory Factor Analysis. 


\subsection{Observed Outcome of CFA and SEM}

\subsubsection{CFA For Total Measurement Model}

Following conducting CFA for all selected store atmospherics factor to check the measurement model testing. In this step, entity scale items were weighted on their fitting factors and every factor were correlated with each other

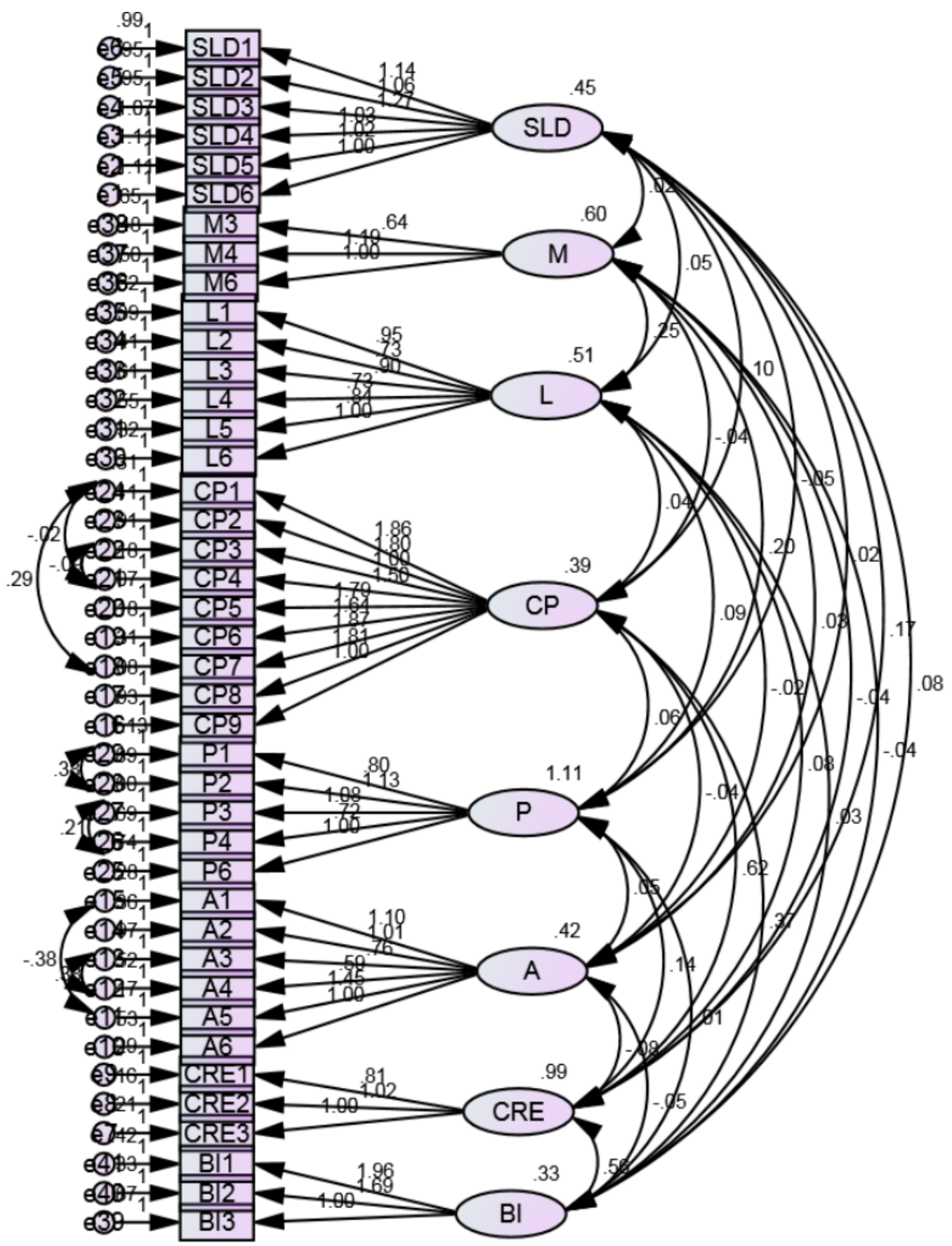

Figure 4 Path Diagram of Final Refined Measurement Model

CFA was carried out for the measurement model that is included of 8 factors measured by 40 scale items. The outcome of CFA for the overall measurement model are shown in table 1 below 
Table 1 CFA Results for Overall Measurement Model

\begin{tabular}{|l|l|l|l|l|l|l|l|}
\hline & $\begin{array}{l}\text { No. } \\
\text { of } \\
\text { Item }\end{array}$ & $\chi^{2}$ (df) & $\boldsymbol{\chi 2}$ /df & CFI & GFI & RMSEA & Results \\
\hline $\begin{array}{l}\text { Initial } \\
\text { Model } \\
\text { Results }\end{array}$ & 43 & $4887.590(1019)$ & 4.796 & $\begin{array}{l}0.813^{*} \\
*\end{array}$ & $\begin{array}{l}0.739^{*} \\
* *\end{array}$ & $0.079^{* *}$ & $\begin{array}{l}\text { Item.M1,M2,M5,P5 } \\
\text { and A3,A4,A6 are } \\
\text { eliminated in } \\
\text { modification }\end{array}$ \\
\hline $\begin{array}{l}\text { Refined } \\
\text { Models } \\
\text { Results }\end{array}$ & 40 & $3337.989(761)$ & 4.386 & $\begin{array}{l}4.386^{*} \\
*\end{array}$ & $\begin{array}{l}0.854^{*} \\
* *\end{array}$ & $0.075^{* *}$ & \\
\cline { 1 - 4 } $\begin{array}{l}\text { Final } \\
\text { Refined } \\
\text { Model } \\
\text { Results }\end{array}$ & 40 & $2852.743(681)$ & 4.189 & $\begin{array}{l}0.869^{*} \\
*\end{array}$ & $\begin{array}{l}0.808^{*} \\
*\end{array}$ & $0.072^{* *}$ & \\
\hline
\end{tabular}

The initial model valves of CFI and RMSEA indicated that the measurement model fit is acceptable except the value of GFI show unacceptable fit of the measurement model.

\subsection{Variances Detailed with Independent Variables in Dependent Variables}

The predicting capability of a model can be accessed by the sum of variance detailed by independent variables in the dependent variables. The superior the amount of variance higher shall be model predicting potential. In structural equation modeling analysis, the value of variance is reported in terms of squared multiple correlations associated to dependent variables. It is equivalent to $\mathrm{R}$ value in Regression Analysis. The squared multiple correlations of dependent variables of the study are shown in table below 2 .

Table 2 Variance Explained by Structural Model

\begin{tabular}{|c|c|c|c|}
\hline $\begin{array}{c}\text { SI. } \\
\text { NO. }\end{array}$ & $\begin{array}{c}\text { Dependent } \\
\text { Variable }\end{array}$ & Independent Variable & $\begin{array}{c}\text { Squared Multiple } \\
\text { Correlation (R) }\end{array}$ \\
\hline 1 & Pleasure & $\begin{array}{c}\text { Store Display and Light, Music, Light and } \\
\text { Cleanliness and participant. }\end{array}$ & 0.684 \\
\hline 2 & Arousal & $\begin{array}{c}\text { Store Display and Light, Music, Light and } \\
\text { Cleanliness and participant. }\end{array}$ & 0.714 \\
\hline 3 & $\begin{array}{c}\text { Customers Retail } \\
\text { Experience }\end{array}$ & $\begin{array}{c}\text { Store Display and Light, Music, Light and } \\
\text { Cleanliness and participant. }\end{array}$ & 0.575 \\
\hline 4 & $\begin{array}{c}\text { Behaviour } \\
\text { Intention }\end{array}$ & $\begin{array}{c}\text { Store Display and Light, Music, Light and } \\
\text { Cleanliness and participant. }\end{array}$ & 0.734 \\
\hline
\end{tabular}

As can be seen from above table the four store atmospheric factors, i. e., store display and layout, store music, store light and store cleanliness and participant act as independent variable's for pleasure, arousal, customer retail experiences and behaviour intention. The four store atmospherics elements explained as $68.4 \%$ of variation in pleasure and $57.4 \%$ of variance in arousal, $71.7 \%$ of variance in customer retail experience and $73.4 \%$ of variance in Behaviour Intention. This means that these entire store atmospherics factor is good enough to predict and well explained emotional behaviour than cognition.

For the customer retail experience, the independent variables are Store Display and Light, Music, Light and Cleanliness and participant. These independent variables explained by $71.7 \%$ of variance in customer retail experience. For the Behavior Intention, the independent variables are Store Display and Light, Music, Light and Cleanliness and participant. These independent variables explained by $73.4 \%$ of variance in Behaviour Intention. This indicates that customer 
retail experience and behavior intention are strongly influenced by both cognitive evaluations based on pleasure and arousal cognitive factors. In overall, these results indicate that model of the present study can forecast and clarify the buyer behaviour and responses in terms of store atmospherics-based shoppin

\subsection{Hypothesis testing Results and Interpretaion}

The effect of store display and layout are assessed by the following hypothesis:

HI: Store layout and display significantly influences on pleasure, arousal, customer's retail experiences and behaviour intention and customers retail experiences and behaviour intention

Table 3 Regression Coefficient and other statistics of Store layout and Display on pleasure, arousal,

\begin{tabular}{|c|c|c|c|c|c|c|}
\hline Hypothesis & & $\begin{array}{c}\text { Hypothesis's } \\
\text { Statements }\end{array}$ & $\begin{array}{c}\text { Regression } \\
\text { Coefficient }\end{array}$ & $\begin{array}{c}\text { Standard } \\
\text { Error }\end{array}$ & $\begin{array}{c}\text { Critical } \\
\text { Ratio }\end{array}$ & Results \\
\hline H1 & H1a & $\begin{array}{c}\text { Store layout and } \\
\text { display on pleasure, }\end{array}$ & $0.45^{*}$ & & & Significant \\
\cline { 2 - 7 } & H1b & $\begin{array}{c}\text { store layout and } \\
\text { display on pleasure, } \\
\text { arousal, }\end{array}$ & $0.11^{*}$ & & Significant \\
\cline { 2 - 7 } & H1c & $\begin{array}{c}\text { store layout and } \\
\text { display on pleasure, } \\
\text { arousal, }\end{array}$ & $0.30^{*}$ & & Significant \\
\cline { 2 - 7 } & H1d & $\begin{array}{c}\text { store layout and } \\
\text { display on pleasure, } \\
\text { arousal, }\end{array}$ & $0.5^{*}$ & & Significant & \\
\hline
\end{tabular}

Finding: The regression coefficient of store display and layout on pleasure (0.45), arousal $(0.11)$ and customer retail experience (0.30) and behaviour intention (0.5) are statically significant and positive. The hypothesis's related to the effects of store display and layout on effective evaluation in pleasure (H1a) arousal (H1b), Customer retail experiences (H1c) and behaviour intention (H1d) were accepted.

\subsubsection{Music}

The effect of music is assessed by the following hypothesis:

HI: Store music significantly influences on pleasure, arousal, customers retail experiences and behaviour intention

The regressions wrights of store music on pleasure, arousal, and customer retail experiences and behaviour intention in below table 3 .

Table 4 Regression Coefficient and other Statistics of Music

\begin{tabular}{|c|c|c|c|c|c|c|}
\hline Hypothesis & & Hypothesis Statements & $\begin{array}{c}\text { Regression } \\
\text { Coefficients }\end{array}$ & $\begin{array}{c}\text { Standard } \\
\text { Error }\end{array}$ & $\begin{array}{c}\text { Critical } \\
\text { Ratio }\end{array}$ & Results \\
\hline \multirow{3}{*}{$\mathrm{H} 2$} & $\mathrm{H} 2 \mathrm{a}$ & Store Music on pleasure, & $0.29^{*}$ & & & Significant \\
\cline { 2 - 7 } & $\mathrm{H} 2 \mathrm{~b}$ & Store Music on arousal, & -0.02 & & & $\begin{array}{c}\text { Not } \\
\text { Significant }\end{array}$ \\
\cline { 2 - 7 } & $\mathrm{H} 2 \mathrm{c}$ & $\begin{array}{c}\text { Store Music on customer } \\
\text { retail experience, }\end{array}$ & -3.01 & & $\begin{array}{c}\text { Not } \\
\text { Significant }\end{array}$ \\
\cline { 2 - 7 } & $\mathrm{H} 2 \mathrm{~d}$ & $\begin{array}{c}\text { Store Music on } \\
\text { Behaviour Intention, }\end{array}$ & -0.02 & & $\begin{array}{c}\text { Not } \\
\text { Significant }\end{array}$ \\
\hline
\end{tabular}


Finding: The regression coefficient of music on pleasure (0.29), arousal (-0.02) and customer retail experience $(-0.301)$ and behaviour intention $(-0.02)$ are statically not significant and negative. The hypothesis's related to the effects of store music on effective evaluation in pleasure (H2a) arousal (H2b), Customer retail experiences $(\mathrm{H} 2 \mathrm{c})$ and behaviour intention $(\mathrm{H} 2 \mathrm{~d})$ were rejected.

\subsubsection{Lights}

The effect of store light is assessed by the following hypothesis:

HI: Store Light significantly influences on pleasure, arousal, customers retail experiences and behaviour intention.

Table 5 Regression Coefficient and other statistics of Light

\begin{tabular}{|c|c|c|c|c|c|c|}
\hline Hypothesis & & $\begin{array}{c}\text { Hypothesis's } \\
\text { Statements }\end{array}$ & $\begin{array}{c}\text { Regression } \\
\text { Coefficients }\end{array}$ & $\begin{array}{c}\text { Standard } \\
\text { Error }\end{array}$ & $\begin{array}{c}\text { Critical } \\
\text { Ratio }\end{array}$ & Results \\
\hline & H3a & Store light on pleasure, & $0.05^{*}$ & & & Significant \\
\cline { 2 - 7 } & H3b & Store light on arousal, & -0.30 & & & $\begin{array}{c}\text { Not } \\
\text { Significant }\end{array}$ \\
\cline { 2 - 7 } & H3c & $\begin{array}{c}\text { Store light on customer } \\
\text { retail experiences, }\end{array}$ & -0.02 & & & $\begin{array}{c}\text { Not } \\
\text { Significant }\end{array}$ \\
\cline { 2 - 7 } & H3d & $\begin{array}{c}\text { Store light on behaviour } \\
\text { intention, }\end{array}$ & $0.62^{*}$ & & & $\begin{array}{c}\text { Not } \\
\text { Significant }\end{array}$ \\
\hline
\end{tabular}

Finding: The regression coefficient of store light on pleasure $(0.05)$, arousal $(-0.30)$ and customer retail experience (-0.02) and behaviour intention $(0.62)$ are statically not significant and negative. The hypothesis related to the effects of store light on effective evaluation in pleasure (H3a) arousal (H3b), Customer retail experiences $(\mathrm{H} 3 \mathrm{c})$ and behaviour intention $(\mathrm{H} 3 \mathrm{~d})$ partially accepted.

The value of regression coefficient on pleasure $(0.05)$ is positive and statistically significant. The hypothesis related to the influence of store light on pleasure (H3a) is accepted. This indicated that store light significantly influences' the feeling of happiness or pleasure.

The value of regression coefficients on arousal $(-0.30)$ is negative and statistically insignificant. The hypothesis related to the influence of store light on arousal (H3b) is not accepted. This indicated that store light is not significantly influences' the arousal.

\subsubsection{Cleanliness and Participant factor}

The effect of store cleanliness and participants are assessed by the following hypothesis:

HI: Store cleanliness and participants significantly influences on pleasure, arousal, customers retail experiences and behaviour intention.

Table 6 Regression Coefficients and other Statistics of Store cleanliness and participants on pleasure, arousal, and customers retail experiences and behaviour intention

\begin{tabular}{|c|c|c|c|c|c|c|}
\hline Hypothesis & & $\begin{array}{c}\text { Hypothesis's } \\
\text { Statements }\end{array}$ & $\begin{array}{c}\text { Regression } \\
\text { Coefficients }\end{array}$ & $\begin{array}{c}\text { Standard } \\
\text { Error }\end{array}$ & $\begin{array}{c}\text { Critical } \\
\text { Ratio }\end{array}$ & Results \\
\hline \multirow{3}{*}{$\mathrm{H} 4$} & $\mathrm{H} 4 \mathrm{a}$ & $\begin{array}{c}\text { Store cleanliness and } \\
\text { participants on } \\
\text { pleasure, }\end{array}$ & $0.14^{*}$ & & & Significant \\
\cline { 2 - 7 } & $\mathrm{H} 4 \mathrm{~b}$ & $\begin{array}{c}\text { Store cleanliness and } \\
\text { participants on arousal, }\end{array}$ & $0.62^{*}$ & & & Significant \\
\hline
\end{tabular}




\begin{tabular}{|l|l|c|c|l|l|l|}
\hline & H4c & $\begin{array}{c}\text { Store cleanliness and } \\
\text { participant's customer } \\
\text { retail experience's, }\end{array}$ & $0.54^{*}$ & & & Significant \\
\cline { 2 - 6 } & H4d & $\begin{array}{c}\text { Store cleanliness and } \\
\text { participants on } \\
\text { behaviour intention, }\end{array}$ & $0.17^{*}$ & & & Significant \\
\hline
\end{tabular}

Finding: The regression coefficient of store cleanliness and participant on pleasure (0.14), arousal (0.62) and customer retail experience (0.54) and behaviour intention (0.17) are statically significant. The hypothesis's related to the effects of store CP on effective evaluation in pleasure (H4a) arousal (H4b), Customer retail experiences $(\mathrm{H} 4 \mathrm{c})$ and behaviour intention $(\mathrm{H} 4 \mathrm{~d})$ fully accepted. The value of regression coefficients on pleasure $(0.14)$ is positive and statistically significant. The hypothesis related to the influence of store cleanliness and participant on pleasure (H4a) is accepted. This indicated that store this factor significantly influences' the feeling of happiness or pleasure.

The value of regression coefficients on arousal (0.62), is positive and statistically significant. The hypothesis related to the influence of store cleanliness and participant on pleasure $(\mathrm{H} 4 \mathrm{~b})$ is accepted. This indicated that store cleanliness and participant significantly influences' the excitement feeling of arousal.

The value of regression coefficients on cleanliness and participant $(0.54)$ is positive and statistically significant. The hypothesis related to the influence of store cleanliness and participant on arousal $(\mathrm{H} 4 \mathrm{c})$ is accepted.

This indicated that store cleanliness and participant is significantly influences' the overall store stratification with shopping of cleanliness and participant

\subsubsection{Pleasures}

The effect of store cleanliness and participants are assessed by the following hypothesis:

HI: Store pleasure significantly influences on pleasure, arousal, customers retail experiences and behaviour intention.

Table 7 Regression Coefficient and other statistics of pleasure, on customers retail experiences and behaviour intention.

\begin{tabular}{|c|c|c|c|c|c|c|}
\hline Hypothesis & Hypothesis's Statements & $\begin{array}{c}\text { Regression } \\
\text { Coefficients }\end{array}$ & $\begin{array}{c}\text { Standard } \\
\text { Error }\end{array}$ & $\begin{array}{c}\text { Critical } \\
\text { Ratio }\end{array}$ & Results \\
\hline & H5a & $\begin{array}{c}\text { Store pleasure on customer } \\
\text { retail experience's, }\end{array}$ & 0.06 & & & $\begin{array}{c}\text { Not } \\
\text { Significant }\end{array}$ \\
\cline { 2 - 7 } H5 & H5b & $\begin{array}{c}\text { Store pleasure on } \\
\text { behaviour intention }\end{array}$ & $0.19^{*}$ & & & Significant \\
\hline
\end{tabular}

Findings: The regression coefficient of store pleasure on customer retail experience $(0.06)$ and behaviour intention (0.19) are statically not significant and negative. The hypotheses related to the effects of store pleasure on effective evaluation in pleasure (H5a) arousal (H5b), fully accepted.

\subsubsection{Arousal}

HI: Store arousal significantly influences on pleasure, arousal, customers retail experiences and behaviour intention. 
Table 8 Regression Coefficients and other statistics of Store cleanliness and participants on pleasure, arousal, and customers retail experiences and behaviour intention.

\begin{tabular}{|l|l|l|l|l|l|l|}
\hline Hypothesis & & Hypothesis's Statements & $\begin{array}{l}\text { Regression } \\
\text { Coefficients }\end{array}$ & $\begin{array}{l}\text { Standard } \\
\text { Error }\end{array}$ & $\begin{array}{l}\text { Critical } \\
\text { Ratio }\end{array}$ & Results \\
\hline \multirow{3}{*}{ H6 } & H6a & $\begin{array}{l}\text { Store arousal on customer } \\
\text { retail experience's, }\end{array}$ & 0.53 & & & Significant \\
\cline { 2 - 6 } & H6b & $\begin{array}{l}\text { Store arousal on behaviour } \\
\text { intention }\end{array}$ & $0.05^{*}$ & & & Significant \\
\hline
\end{tabular}

Findings: The regression coefficient of store pleasure on customer retail experience $(0.53)$ and behaviour intention (0.05) are statically significant.

The hypothesis related to the influence of arousal on customer retail experience's (H6a) is accepted. This indicated that store arousal significantly not influences' the store satisfaction.

The value of regression coefficients of arousal on behaviour intention (0.05), is statistically significant. The hypothesis related to the influence of arousal on behaviour intention (H6b) is accepted. This indicated that store arousal significantly influences' the response of customers.

\subsection{The Finding of The Study, Summarized as Follow}

The study developed a model supported to the traditional Stimulus-Organism-Responses (SOR) model in organize to detain consumer shopping behaviour towards an Apparel store. The satisfactory model fit of the proposed research model and the variance explained by independent variables in dependents variable's recommended that the model possibly will be efficient to depict consumer's perception towards Apparel store environmental stimuli and behaviour responses towards Apparel store. The study model conform to the traditional SOR paradigm; that is; the stimuli (refers as store atmospheric factors) has an effects on the organism (direct effect on emotion state is pleasure and arousal), which is turn influenced the responses behaviour (sales, recommendation to the store, revisit)

\section{CONCLUSION}

This study developed an empirical framework to depict the relationship between Apparel store atmospheric factors (store layout and display, Music, Light and Cleanliness and Participant), customer's emotional states (pleasure, arousal) and behaviour state (customer retail experiences and behaviour intention). The structural equation modeling technique applied for the framework revealed significant results confirming the SOR model. These results imply that both academicians and retail mangers can adopt this model evaluate the SOR model not just in the context of one or two stimuli as well as emotions as organism, but can extend by including additional input and mediating variables when there is a need model more comprehensively. Finding of the study indicate significantly impact of store atmospherics on both on cognitive and affective states of the customers. Different factors of store atmospherics have varying influences on customer perception and shopping behaviour.

\section{REFERENCES}

[1] Areni, C.S. and Kim, D. 1993. The Influence of Background Music on Shopping Behavior: Classical versus

[2] Areni, C S., \&Kim D. 1994. The influence of Background Music on Shopping Behaviour: Classical Versus Top - Forty Music in a Wine store. Advances in Consumer Research, 20, no.1: 336-340. 
[3] A T Kearney, 2006. Retail in India, Getting Organized to Drive Growth, CII Report, New Delhi, India, p. 57-58.

[4] AT Kearney, 2011. The Global Retail Development Index, Lessons Learned from Decade of Retail Expansion, CII Report, New Delhi, India, 40-48.

[5] AT Kearney, 2014.The Global Retail Development Index,Full Steam Ahead for Global Retailers, CII Report, New Delhi, India, 40-48.

[6] AT Kearney, 2013.Global Retailers Cautiously Aggressive or Aggressively Cautious?CII Report, New Delhi, India, 4-29.

[7] ASA \& Associates 2015. Retail Sector in India, New Delhi, India, p.4-9.

[8] Agnihotri, A., \& Oburai, P. 2009. Shoppers Interaction with Visual Merchandising Elements in Organized Grocery Stores," 3rd IIMA Conference on Marketing Paradigms for Emerging Economies. Ahmedabad.

[9] Bell, Paul, Morris H., \& Micheal S. 1991. Combining esthetic and social value to explain preferences for product styles with the incorporation of personality and ensemble effect. Journal of Social Behavior and Personality, 6: 243-273

[10] Bell, P., Holbrook, M., \& Solomon, M. 1991. Combining esthetic and social value to explain preferences for product styles with the incorporation of personality and ensemble effects. Journal of Social Behavior and Personality, 6: 243-273

[11] Bagozzi. R. 1994. Advanced methods in marketing research. Cambridge (MA): Basil Blackwell.

[12] Baker, J., Parasuraman, A., Grewal, D. \& Voss, G.B. 2002. The influence of multiple store environment cues on perceived merchandise value and patronage intention. Journal of Marketing, 66, no.4: 120-144.

[13] Bruner, Gordon II. 1990. Music, Mood and marketing. Journal of Marketing, 54, no..4: 94100 .

[14] Berman, B., \& Evans, J.R. (1995). Retail Management: Retail Management: A Strategic Approach, ${ }^{\text {th }}$ Ed. Pretice-Hall.

[15] BDO 2012. Adversary Foreign Direct Investment in India's Single and Multi Retail: New Opportunity \& Developments",A Joint White Paper, Advisory report, New Delhi, India, p.3-6

[16] Boston Consultancy Group, 2015.Retail 2020: Retrospect, Reinvest, Rewrite, leadership Prospective Trends in Indian retails, Mumbai, India, p.32-48.

[17] Bainbridge, J. 1998, February 19. Science Opportunities. Marketing, 36-37

[18] Bitner, M.J. 1992. Evaluating Services Encounters: The Effects of Physical Surrounding and Employee.Journal of Marketing, 56. no. 2: 57-71.

[19] Bawa, Kapil, Landwehr, Jane T., and Krishna, Aradhna. 1989. Consumer Response to Retailers' Marketing Environments: An Analysis of Coffee Purchase Data. Journal of Retailing, 65, no. 7: $471-495$.

[20] Baker, J., Levy, M., \& Grewal, D. 1992. “An Experimental Approach to Making Retail Store Environmental Decisions”.Journal of Retailing, 68, no. 4: 445-460. 
[21] Bowman, John S., ed. 1985. The Vietnam War: An almanac. New York, NY: World Almanac Publications

[22] Baker, J., Grewal, D., Parasuraman, A. 1994. The influence of store environment on quality inferences and store image. Journal of the academy marketing science, 22, no.4 (1994): 328 339.

[23] Bone, Paula F. and Swati Jantrania. 1992. Olfaction as a cue for product quality. Marketing Letters". Journal of Retailing, 3, no.3:289-296.

[24] Bitner, M. J. 1990. Evaluating Services Encounters: The Effects of Physical Surrounding and Employee. Journal of Marketing, 13, no. 1:119-126.

[25] Belk, R.W. 1975. Situational variables and consumer behaviour. Journal of Consumer Research, no. 2: $157-64$.

[26] Bloch, P. H., Brunel, F. F., \& Arnold, T. J. 2003. Individual differences in the centrality of visual aesthetics: concept and measurement, Journal of Consumer Research, John Deighton, USA, Vol. 29, no. 4: 551-66.

[27] Bitner, M. J. 1990. Evaluating Services Encounters: The Effects of Physical Surrounding and Employee. Journal of Marketing, 13, no.1: 119-126.

[28] Caldwell, C. \&Hibbert, S.A. 2002. The influence of music tempo and musical preference on restaurant patron's behavior. Psychology and Marketing, 19, no.1: 895-917.

[29] Campo, K., Gijsbrechts, E., Nisol, P., 2000. Towards understanding consumer response to stock-outs. Journal of Retailing, 76, no 2:219-242.

[30] Cant, M.C., Brink, A. \& Brijball, S. 2006. Consumer behaviour. Cape Town: Juta.

[31] Curhan, Ronald C. 1972. The Relationship between Shelf Space and Unit Sales in Supermarkets. Journal of Marketing Research, 9, no.7: 406-412.

[32] Census of India 2011. Provisional Population Totals Urban Agglomerations and Cities, India, p. 2-4.

[33] Crosby,L.A.,1990.Relationship quality inservice sselling:An interpersonal influence

[34] Davies, J., \& Tilley, N. 2004. Interior Displays: Using theManagement Services Approach in RetailPremises.Managing Services 10,no. 48:10-13.

[35] Dube, Laurette, Jean-Charles Chebat \& Sylvie Morris 1995. The Effects of Background Music on Consumers.

[36] Diamond Jay and Diamond Ellen, 2007. Contemporary Visual Merchandising and Environmental Design, Pearson education: New Jersey.

[37] Deloitte 2014. Global Power of Retailing, Retail Beyond begins, London, p.20-35.

[38] Deloitte 2013. Global Powers of Retailing, Retail Beyond, London, p.20-35

[39] Dhar, S.K., Hoch, S.J and Kumar, N., 2001. Effective Category Management depends on the role of category, Journal of Retailing 77, no. 2: 165-84. 
[40] Donovan, R.J., \& Rossiter, J.R 1982. "Store atmosphere: An environmental psychology approach". Journal of Retailing, 58, no.2: 34-57.

[41] De Young R. ed. 1999.Environmental Psychology In: Alexander, D.E., \& Fairbridge, R.W. Encyclopedia of Environmental Science MA: Kluwer Academic Publisher.

[42] Davies, J., \& Tilley, N. 2004. Interior Displays: Using theManagement Services Approach in RetailPremises.Managing Services no.7: 10-13.

[43] Donovan, R.J., Rossiter, J.R., Marcoolyn, G., \& Nesdale, A. 1994. Store atmosphere and purchasing behavior. Journal of Retailing, 70, no.3: 283-294.

[44] Evans, M., Jamal, A. \& Foxall, G. 2nd ed. 2010. Consumer behaviour. England: John Wiley and Sons.

[45] Ellis, L. \& Ficek, C. 2001. Color preferences according to gender and sexual orientation Personality and Individual Differences. Journal of Retailing, 31, no.4: 1375-1379.

[46] Fournier, S. 1998.Consumer and their brands: developing relationship theory in consumer research .Journal of Consumer Research, 24: 343-73.

[47] Gopal, V. 2006. VisualMerchandising: An Introduction, no. 5: 4-5.

[48] Garlin, F.V. \& Owen, K. 2006. Setting the tone with the tune: a meta-analytic reviewof the effects of background music in retail settings. Journal of Business Research, 59, no. 6:755-764.

[49] Goulding, C., 2005. A comparative Analysis of three Qualitative Strategies for Marketing Resaerch. European Journal of Marketing 39, no.3: 294-308.

[50] Garden, M.P, 1985.Mood States and Consumer Behaviour: A critical Review.Journal of Consumer Research, 12, no.3: 281-300.

[51] Gajanayake R., Gajanayake S., Surangi, H.A.K.N.S.2011.The impact of selected visual merchandising techniques on patronage intentions in supermarket.Unpublished Ph.D. diss., University of Kelaniya, Sri Lanka.

[52] Gupta, S. \& Randhawa, G. 2008. Retail managementNew Delhi: Atlantic.

[53] Harris K., Harris R., \& Baron, S. 2001. Customer participation in retail services: lessons from Brecht. International Journal of Retail \& Distribution Management, 29, 8: 359-369.

[54] Hawkins, D.I. \& Mothersbaugh, D.L 2010.Consumer behaviour. 11th ed.Building marketing strategies. New York: McGraw-Hill.

[55] Hultén, B. 2011. Sensory marketing: The multi-sensory brand-experience concept.European Business Review, 23, no. 3: 256-273.

[56] Hasty, R.W. \& Reardon, J. 1996. Retail Management, New York: McGraw Hill.

[57] IBEF 2008. Investment Climate in Uttar Pradesh, Gurgaon, India: p.4-21

[58] Jang, S.S. \& Namkung, Y. 2009. Perceived quality, emotions and behavioral intentions: Application of an extended Mehrabian-Russell model to restaurants. Journal of Business Research, no. 62: 451-460. 
[59] Klokis, H. 1986. Store windows: Dynamic first impressions. Chain Store Age Executive, 62:108-109.

[60] Kellaris, J.J. and Mantel, S.P. 1996. Shaping Time Perceptions with Background Music: The Effect of Congruity and Arousal on Estimates of Ad Durations. Psychology \& Marketing, 13, no. 5: 501-515.

[61] KPMG 2014. Indian Retail the Next Growth Story, USA: P.20-48

[62] KPMG 2013. Retail Industry Overlook Survey, Tech Innovation leads to brighten future, USA, p.20-48.

[63] Kotler, P. \& Keller, K.L., 2009. A framework for marketing management integrated with

[64] Kerfoot, S., Davies, B., \& Ward, P. 2005. Visual merchandising and the creation of discernible retail brands. International Journal of Retail \& Distribution Management, 31, no.3:143-15.

[65] Kardes, F.R., Cline, T.W. \& Cronley, M.L. ed. 2011. Consumer behaviour: Science and practice. China: South-Western Cen gage Learning.

[66] Koekemoer, L. 2011. Introduction to integrated marketing communications. CapeTown: Juta.

[67] Kotler, Philip, $11^{\text {th }}$. ed, 2004. Marketing Management, Prentice Hall of India Pvt. Ltd: New Delhi.

[68] Kotler, 1973. Atmospheric as a Marketing Tool. Journal of Retailing 49, no. 4: 48-64.

[69] Levy, M. \& Weitz, B.A. $5^{\text {th }}$ ed. 2004. Retailing Management. New York: McGraw - Hill

[70] Levy, M., Weitz, B.A. \& Beitelspacher, L.S. 8th Ed.2012. Retailing management. New York: McGraw-Hill.

[71] Levy, M., Weitz, B., 1998. Retailing management. McGraw-Hill, Boston, MA (Chapters 16 \& $18)$.

[72] Mattila, A.S., \& Wirtz, J. 2002. Congruency of scent and music as a driver of in- store evaluations and behavior. Journal of Retailing, 77, 2: 273-289.

[73] Milliman, R.E. 1982. Using background music to affect the behavior of supermarket shoppers.Journal of Marketing, 46, no.2: 86-91.

[74] Mills, K. H., Paul, J. E., \& Moorman, K. B. 1995. Apparel visual merchandising. 3rd ed. Englewood Cliffs, NJ: Prentice-Hall.

[75] Milliman, R.E, 1986. The Influenceof Background MusicontheBehaviorof Restaurant Patrons. JournalofConsumerResearch, no.4: 286-289.

[76] McGoldrick, P. and Thompson, M. 1992. Regional Shopping Centres, Aldershot: Avebury,

[77] Mehrabian, A., \& Russell, J.A. 1974. An approach to environmental psychology.

[78] McGraw-Hill.Sirgy, Grewal\&Mangelburg 2002 .Journal of Business Research, 49:127-138.

[79] Oakes, S. \& North, A.C. 2008. Using music to influence cognitive and affective responses in queues of low and high crowd density. Journal of Marketing Management, 24, no. 5-6, (2008): 589-602 
[80] Pegler, M.M. $5^{\text {th }}$ ed. 2010. Visual merchandising and display. China:Fairchild

[81] Parumasur, S.B. \& Roberts-Lombard, M 2012. “Consumer behaviour”. 2nd Ed.CapeTown: Juta.

[82] PWC 2015. The Indian Kaleidoscope emerging trends in retail report on Indian retail industry,New Delhi, India, p.7-24.

[83] PwC 2012. Retailers and the age of disruption, New Delhi, India, p.7-24..

[84] Piyush Kumar Sinha and Dwarika Prasad Uniyal. 2007. "Managing Retailing Lost Forever in a Shopping Mall”, Oxford University Press,New Delhi.

[85] Pradhan, S. 2nd ed. 2007. Retailing management: Text and cases New Delhi: Tata McGrawHill.

[86] Rook, D. W. \& Hoch, S.J. 1985. Consuming Impulses.Advances in Consumer Research, 12, no: 23-7.

[87] Snyder, M. 1974. Self-monitoring of expressive behaviour, Journal of Personality and Social Psychology, American Psychological Association USA 51, no. 1: 526-37.

[88] Sinha, P.K., Mathew, E. and Kansal, A. 2005. Format choice of food and grocery retailer, Working Paper No. (2005-07-04): IIMA.

[89] Sinha, P.K. and Banerjee., 2004. A Store choice behavior in an evolving market. International Journal of Retail \& Distribution Management 32, no.10: 482-94.

[90] Smith, Peter, and Burns, David J.1996.Atmospherics and Retail Environments:The Case of the "PowerAisle.'International Journal of Retail and Distribution Management, 24, no. 7:14.

[91] Schiffman, L.G. \& Kanuk, L.L. 8th ed. 2004. Consumer behaviour. USA: PearsonPrentice Hall.

[92] Spangenberg, E.R., Crowley, A.E., \& Henderson, P.W. 1996. Improving the store environment: Do olfactory cues affect evaluations and behaviors? Journal of Marketing, 60, no. 2: 67-80.

[93] Sharma, A. and Stafford, T.F. 2000. The effect of retail atmospherics on customers' perceptionsof salespeople and customer persuasion: an empirical investigation.Journal of Business Research, 49, no. 2:183-191.

[94] Sinha PK, Banerjee A, Uniyal DP 2002. Deciding Where to Buy: Choice Behaviour of Indian Shoppers, Vikalpa .27, no.2: 13-28.

[95] Summers \& Hebert. 2001. Shedding Some Light on Store Atmospherics: Influence of Illumination on Consumer Behavior. Journal of Business Research, 54, no.2:145-150; as cited in Vaccaro, Yucetepe, Baumgarten \& Lee (2008).

[96] Smith, P.C. and Curnow, R. 1966. Arousal Hypothesis and the Effects of Music on Purchasing Behavior. Journal of Applied Psychology,50, no. 3: 255-256.

[97] Sweeney, J.C. and Wyber, F. 2002. The Role of Cognitions and Emotions in the Music Approach - Avoidance Behavior Relationship. Journal of Services Marketing, 16, no. 1: 51-69.

[98] Sirgy, Grewal \& Mangelburg, 2000. Journal ofBusiness Research, no. 49: 127-138.

[99] Underhill P.1999. Whywe buy.New York: Simon\&Schuster. 
[100] Uhrbrock, R.S., 1961.Music on the job: its influence on worker morale and production Personal psychology, 14, no.1 9-38.

[101] Wanninayake, W. M. C. B. \& Randiwala, P. 2007. The impact of visual merchandising on consumer: Store choice decision in" Sri Lakan Supermarket. $7^{\text {th }}$ Global Conference on Business \& Economics, ISBN: 978-0-9742114-9-4:1-16.

[102] Walters, D and White, D. 1987. Retail Marketing Management, Basingstoke, 1987: (Macmillan Press: 2007).

[103] Woodworth, R.S. ed. 1928. Dynamic psychology: In C. Murchison, ed. Psychologies of, 1925.

[104] Wilson, S. 2003. The effect of music on perceived atmosphere and purchase intentions in a restaurant. Journal of Retailing, Psychology of Music, 31, no. 1: 93-112

[105] Wall, E. A., \& Berry, L. L., 2007. The Combined Effects of the Physical Environment and Employee Behavior on Customer Perception of Restaurant Service Quality. Cornell Hotel and Restaurant Administration Quarterly, 48, no.1: 59-12.

[106] Yalch, R.E and Spengerberg, E.R. 1990. Effects of Store Music on Shopping Behaviour. Journal of Consumer Marketing. 7, no.2: 55-63.

[107] Yalch, R.F. and Spangenberg, E.R. 1993. Using Store Music for Retail Zoning: A Field Experiment in Advances in Consumer Research, 20, L. McAlister and M.L. Rothschild, Eds. Provo, UT: Association for Consumer Research, 632-636.

[108] Zakay, Dan, Nitzan, Devora, and Glicksohn, Joseph 2000: The Influencenal of Business Research 49, no. 7:193-211. of Task Difficulty and External Tempo on Subjective Time

[109] Zainbooks. 2008. "Consumer buying behaviour". Accessed December 11, 2013. (Online) Availablefrom:http://www.zainbooks.com/books/marketing/principles-of marketing_15_consumerbuying-behavior.html 